\title{
A two-genome microarray for the rice pathogens Xanthomonas oryzae pv. oryzae and $X$. oryzae $p v$. oryzicola and its use in the discovery of a difference in their regulation of hrp genes Young-Su Seo ${ }^{\dagger 1}$, Malinee Sriariyanun ${ }^{\dagger 1}$, Li Wang ${ }^{2,6}$, Janice Pfeiff ${ }^{3}$, Jirapa Phetsom1, Ye Lin ${ }^{4}$, Ki-Hong Jung1, Hui Hsien Chou, ${ }^{4}$, Adam Bogdanove ${ }^{2}$ and Pamela Ronald*1
}

\begin{abstract}
Address: ${ }^{1}$ Department of Plant Pathology, University of California, Davis, CA 95616 USA, ${ }^{2}$ Department of Plant Pathology, Iowa State University, Ames, IA 50011 USA, ${ }^{3}$ ArrayCore Facility, School of Veterinary Medicine, Molecular Biosciences, University of California, Davis, CA 95616, USA, State University, Ames, IA 50011, USA and ' Department of Biochemistry and Molecular Biology, Medical University of South Carolina, Charleston, SC 29425, USA

Email: Young-Su Seo - yseo@ucdavis.edu; Malinee Sriariyanun - msriar@ucdavis.edu; Li Wang - liw25@musc.edu; Janice Pfeiff - jmpfeiff@ucdavis.edu; Jirapa Phetsom - phetsom2000@yahoo.com; Ye Lin - yelin@iastate.edu; KiHong Jung - kjung@ucdavis.edu; Hui Hsien Chou - hhchou@iastate.edu; Adam Bogdanove - ajbog@iastate.edu; Pamela Ronald* - pcronald@ucdavis.edu

* Corresponding author †Equal contributors
\end{abstract} ${ }^{4}$ Department of Computer Science, Iowa State University, Ames, IA 50011, USA, ${ }^{5}$ Department of Genetics, Development and Cell Biology, Iowa

Published: 18 June 2008

BMC Microbiology 2008, 8:99 doi:10.1186/147|-2180-8-99
Received: 19 February 2008

Accepted: 18 June 2008

This article is available from: http://www.biomedcentral.com/I47|-2/80/8/99

(C) 2008 Seo et al; licensee BioMed Central Ltd.

This is an Open Access article distributed under the terms of the Creative Commons Attribution License (http://creativecommons.org/licenses/by/2.0), which permits unrestricted use, distribution, and reproduction in any medium, provided the original work is properly cited.

\begin{abstract}
Background: Xanthomonas oryzae pv. oryzae (Xoo) and X. oryzae pv. oryzicola (Xoc) are bacterial pathogens of the worldwide staple and grass model, rice. $X_{0 o}$ and $X o c$ are closely related but $X_{0 o}$ invades rice vascular tissue to cause bacterial leaf blight, a serious disease of rice in many parts of the world, and Xoc colonizes the mesophyll parenchyma to cause bacterial leaf streak, a disease of emerging importance. Both pathogens depend on $h r p$ genes for type III secretion to infect their host. We constructed a 50-70 mer oligonucleotide microarray based on available genome data for $X_{00}$ and Xoc and compared gene expression in Xoo strains PXO99A and Xoc strain BLS256 grown in the rich medium PSB vs. XOM2, a minimal medium previously reported to induce hrp genes in Xoo strain T7/74.

Results: Three biological replicates of the microarray experiment to compare global gene expression in representative strains of $X_{0 o}$ and Xoc grown in PSB vs. XOM2 were carried out. The non-specific error rate and the correlation coefficients across biological replicates and among duplicate spots revealed that the microarray data were robust. 247 genes of Xoo and 39 genes of Xoc were differentially expressed in the two media with a false discovery rate of $5 \%$ and with a minimum fold-change of 1.75 . Semi-quantitative-RT-PCR assays confirmed differential expression of each of 16 genes each for Xoo and Xoc selected for validation. The differentially expressed genes represent 17 functional categories.
\end{abstract}

Conclusion: We describe here the construction and validation of a two-genome microarray for the two pathovars of $X$. oryzae. Microarray analysis revealed that using representative strains, a greater number of Xoo genes than Xoc genes are differentially expressed in XOM2 relative to PSB, and that these include $h r p$ genes and other genes important in interactions with rice. An exception was the rax genes, which are required for production of the host resistance elicitor AvrXa2I, and which were expressed constitutively in both pathovars. 


\section{Background}

The rice pathogens Xanthomonas oryzae pathovar oryzae (Xoo) and Xanthomonas oryzae pathovar oryzicola (Xoc) cause economically significant disease in many rice-growing regions of the world [1]. Xoo invades rice vascular tissue to cause bacterial leaf blight, whereas Xoc colonizes the mesophyll parenchyma tissue to cause bacterial leaf streak. Xoo gains access to the xylem through wounds or natural openings such as hydathodes, while Xoc, in contrast, enters the leaf mainly through stomata [2]. Xoo and $X o c$ are closely related, infect the same host, and are often both established in the same rice fields. The complete genome sequences of Japanese Xoo strain T7174 (also called MAFF311018) and Korean Xoo strain KACC10331 have been published $[3,4]$. The genome sequences of a third Xoo strain, Philippine strain PXO99A, and a strain of Xoc, Philippine strain BLS256, have recently been completed and are also publicly available, through the Comprehensive Microbial Resource ([5]; GenBank Accession CP000967). The genomes of Xoo and Xoc strains are similar with respect to size, $\% \mathrm{G}+\mathrm{C}$, and gene content, but show several inversions and rearrangements and some indels relative to one another ( $\mathrm{P}$. Patil and AJB, unpublished). These bacteria constitute an excellent comparative model for understanding determinants of tissue specificity in plant-bacterial interactions. Defining differences in gene expression and gene regulation between Xoo and Xoc is an important step toward that goal.

DNA microarray technology makes it possible to monitor the expression of thousands of genes simultaneously. Microarrays can be of two general types: 1) arrays based on in situ synthesis of oligonucleotide probes, using photochemical techniques or an ink-jet oligonucleotide synthesizer [6,7] and 2) spotted arrays, consisting of presynthesized DNA molecules or oligomers deposited onto glass slides or filter membranes $[8,9]$. Spotted arrays are generally less costly to produce, and because they are spotted rather than synthesized from a template, they constitute a highly flexible design platform.

Currently, oligonucleotide- or amplicon-spotted microarrays representing the whole or partial genomes of the following plant pathogenic bacteria are available: Pseudomonas syringae, Ralstonia solanacearum, Xanthomonas axonopodis, Xanthomonas campestris, and Xylella fastidiosa [10-16]. These arrays, enabled by whole-genome sequence availability, have been used to study responses to environmental cues such as heat shock [13], and to probe gene expression patterns related to pathogenesis $[10,12,15]$. They have also been used to assess genome diversity of isolates of a particular organism by comparative genome hybridization $[11,17]$.

Based on the available genome sequences, we constructed a combined Xoo and Xoc whole genome microarray for both pathovars of $X$. oryzae (Xo) that contains 4,676 distinct 50-70 mer oligonucleotides, representing sequences from 2,153 genes shared by Xoo and Xoc, sequences specific to 1,270 Xoo genes, sequences specific to Xoc 1,252 genes, and a control corresponding to a gene encoding hygromycin phosphotransferase not found in Xoo or Xoc. We present here the details of the microarray design and optimization, and the results of a successful experiment to validate the array by comparing gene expression of strain PXO99A of Xoo and strain BLS256 of Xoc (hereafter "Xoo" or "Xoc" will be used to refer to these specific strains, unless otherwise indicated) in a rich medium vs. XOM2, a minimal medium reported to induce the hrp (hypersensitive reaction and pathogenesis) genes in Xoo strain T7174 $[18,19]$, and by independently assessing the expression of a subset of those genes by semi-quantitative RT-PCR.

In addition to several arbitrarily selected genes, validation by semi-quantitative RT-PCR focused on the hrp and rax genes. The hrp genes encode a type III secretion system (T3SS), which many plant pathogenic bacteria, including $X o o$ and $X o c$, require for $\underline{h}$ ypersensitive reaction elicitation in resistant or non-host plants and for pathogenesis in susceptible host plants [20-22]. Expression of hrp genes is regulated by plant signals as well as in response to environmental stimuli such as carbon source, temperature, and $\mathrm{pH}[23,24]$. The rax genes are required for AvrX 212 activity. AvrXa21 is a pathogen associated molecule recognized by the Xa21 resistance protein [25]. rax genes include eight genes predicted to contribute to three roles: type I secretion, sulfur metabolism and two-component regulation [25-28].

\section{Results and discussion Quality of the Xo array}

We used a diagnostic method developed by Rocke [29] to examine the contribution of different factors to measured differences in signal intensity in 6 hybridizations ( 3 replicates with dye-swaps) comparing Xoo gene expression in PSB vs. XOM2 using the Xo array. This method employs analysis of variance (ANOVA). ANOVA can be used to calculate the gene expression changes in replicated array experiments and to correct systematic errors [30]. Factors examined were treatment, dye, sample, and error (Fig. 1). The treatment factor (red line) had the largest effect whereas the dye, sample, and error effects were much smaller. This analysis indicates that the measured significant changes in gene expression are due to the treatment and not to variability of other parameters.

The non-specific background error rate was assessed using 100 replicate spots of an oligonucleotide probe corresponding to the non-Xo gene encoding hygromycin phosphotransferase $(h p h)$. Across 6 hybridizations each using cDNA prepared from Xoo or Xoc RNA (3 replicates for each pathovar, each with a dye swap), error rates for positive 



Figure I

Cumulative frequency distribution chart of sources of variation in the microarray data. The four different factors, including treatment (XOM2 vs. PSB; treat), RNA sample (sample), Cy5 or Cy3 dye (dye), and unknown sources of variation (error), were considered for this ANOVA analysis. The significance of each factor across the array was evaluated as a frequency distribution of relative mean square values. The frequency was marked as a density on the $Y$ axis. Relative mean square values of the four factors for all genes were obtained and correspond to the significance of the factor, i.e., a larger relative mean square value indicates that the factor is more significant.

artifacts were $0.00-1.00 \%$ and $1.00-2.00 \%$ respectively. That is, less than $2 \%$ of the $h p h$ gene oligonucleotides showed over two-fold differences in signal intensity. Error rates associated with non-spotted controls (632 empty spots) were similarly low, $0.00-0.94 \%$ and $0.00-1.10 \%$ following hybridization with Xoo- and Xoc-derived cDNA, respectively (Additional File 1).

\section{Optimization of hybridization temperature and sample amounts}

To optimize temperature and amount of labeled cDNA sample for hybridization, array performance was assessed at $42,44,48$, and $52^{\circ} \mathrm{C}$ and using labeled cDNA amounts of $10,20,30,40$, and 50 pmol. The mean signal intensity associated with the cyanine dyes and the correlation coefficients in self-self hybridizations were examined. There were no differences in these parameters associated with using high vs. low power of the scanner photomultiplicator (PMT). Hybridization with probe (labelled cDNA amounts of 50 pmol gave the best correlation coefficient values (0.93). For temperature, the best correlation coefficient $(0.87)$ was obtained at $42^{\circ} \mathrm{C}$. A hybridization temperature of $42^{\circ} \mathrm{C}$ and a labeled cDNA amount of $50 \mathrm{pmol}$ resulted in the strongest signals associated with the cyanine dyes (data not shown) and the highest correlation coefficients among arrays (Table 1). Therefore, these parameters were used in all subsequent hybridizations.

\section{Application and validation of the array to identify Xoo and $X o c$ genes differentially expressed in a rich vs. $a$ minimal medium}

Given the distinct tissue specificities of Xoo and Xoc, we reasoned that these two pathovars might regulate the expression of important pathogenesis-associated genes differently. Therefore, we used the microarray to assess whether Xoo and Xoc show distinct patterns of differential gene expression in peptone sucrose broth (PSB) vs. $\mathrm{XOM} 2$, a minimal medium reported to activate $h r p$ gene expression in $\mathrm{Xoo}$, presumably by mimicking the $\mathrm{pH}$ and

Table I: Optimization of hybridization temperature and probe amounts

\begin{tabular}{|c|c|c|c|c|c|}
\hline Amount of probe $(\mathrm{pmol})$ & 10 & 20 & 30 & 40 & 50 \\
\hline HighPMTb & $0.69 c$ & 0.70 & 0.70 & 0.92 & 0.93 \\
\hline LowPMT & 0.72 & 0.73 & 0.71 & 0.93 & 0.94 \\
\hline Hybridization temperature $\left({ }^{\circ} \mathrm{C}\right)$ & 42 & 44 & 48 & 52 & \\
\hline HighPMT & 0.87 & 0.73 & 0.67 & 0.77 & \\
\hline LowPMT & 0.87 & 0.72 & 0.73 & 0.76 & \\
\hline
\end{tabular}

a Probes were generated from RNAs extracted from Xoo cultured in PSB.

b PMT represents power of the scanner photomultiplicator that can influence ratio experimental estimation, dynamical range extension or saturation of highly expressed genes. In this study, we tuned to two (high and low) PMT levels to acquire raw slide pictures.

c value of correlation coefficient in self-self hybridization. 
nutrient content in the apoplast [18]. Individually for Xoo and Xoc, three biological replicates (with a dye-swap, for a total of 6 hybridizations each) were carried out to compare gene expression in the two culture media. Average correlation coefficients across the biological replicates were 0.76 for Xoo and 0.69 for Xoc, respectively (Table 2.).

To identify differentially expressed genes, the LMGene Package [29] was used. The resulting list of genes with significantly different expression between the two growth conditions was then refined using a false discovery rate (FDR) of $5 \%$ and a fold-change minimum of 1.75 ( $\log 2$ ratio value $>0.8$ ), resulting in 247 genes for Xoo and 39 genes for Xoc. Additional File 2 provides a complete list of the differentially expressed Xoo and Xoc genes, sorted according to functional category and fold-change in expression (log2ratio).

To validate these results, semi-quantitative RT-PCR was used to independently assess expression levels for 16 Xoo and 16 Xoc genes selected arbitrarily from the list (genes and primer sets used are given in Table 3, and semi-quantitative RT-PCR results are shown in Additional file 3). RNA samples that were used in the microarray experiment as well as RNA samples extracted from three additional replicate sets of cultures were used as templates. There was good correlation between the semi-quantitative RT-PCR and the microarray results (correlation coefficients were 0.8225 and 0.7791 for Xoo and Xoc genes, respectively, Fig. 2). Although the amplitude of gene expression fold change between the two techniques is different, as might be expected since semi-quantitative RT-PCR is not a reliable measure of quantitative differences, the general trend of gene expression is consistent. For additional verification, we performed quantitative RT-PCR on 5 genes from $X o o$ and 2 from Xoc. In each case the results verified the expression patterns observed using semi-quantitative RTPCR (Additional file 4).

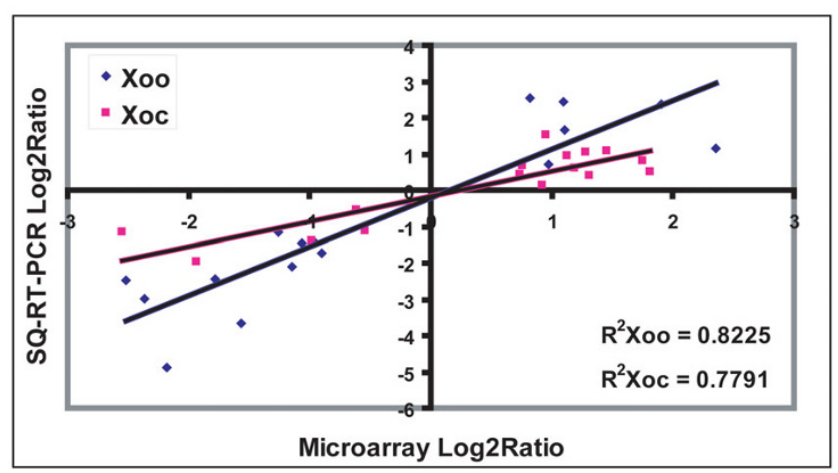

\section{Figure 2}

Comparison of transcription measurements by microarray and semi-quantitative RT-PCR assays in Xoo and Xoc. The relative transcriptional levels for the 16 genes of $X_{o o}$ and $X o c$ were determined by microarray and semi-quantitative RT-PCR. The semi-quantitative RT-PCR $\log 2$ ratio values were plotted against the microarray data log2ratio values. The correlation coefficients $\left(R^{2}\right)$ between the two dataset are 0.8225 and $0.779 \mathrm{I}$ for Xoo and Xoc respectively.

\section{Xoo and Xoc genes differentially expressed in XOM2 relative to $P S B$}

Of the differentially expressed genes, 106 Xoo genes were up-regulated and 141 were down-regulated in XOM2 as opposed to PSB. For Xoc, only 28 and 11 genes were upregulated and down-regulated, respectively, in XOM2 (Additional File 2). These genes represent 17 functional categories, based on the TIGR annotation for the genomes available through the Comprehensive Microbial Resource [5] (Fig. 3). The Xoo genes up-regulated in XOM2 encode primarily hypothetical proteins $(29.2 \%)$ and proteins involved in cellular processes (22.6\%); most of the downregulated Xoo genes encode hypothetical proteins $(34.8 \%)$ or proteins involved in signal transduction

Table 2: Correlation coefficients of technical and biological replicates

\begin{tabular}{|c|c|c|c|c|c|c|c|c|}
\hline \multirow[t]{2}{*}{ Biological replicates } & \multirow[t]{2}{*}{ Pathovar } & \multicolumn{7}{|c|}{ Test slide number } \\
\hline & & I vs 2 & I vs 3 & 2 vs 3 & 4 vs 5 & 4 vs 6 & 5 vs 6 & Average \\
\hline \multirow[t]{2}{*}{ Correlation coefficient } & Xoo & 0.73 & 0.72 & 0.63 & 0.90 & 0.66 & 0.92 & 0.76 \\
\hline & Xoc & 0.71 & 0.71 & 0.72 & 0.66 & 0.67 & 0.66 & 0.69 \\
\hline \multirow[t]{2}{*}{ Technical replicates } & Pathovar & \multicolumn{7}{|c|}{ Test slide number } \\
\hline & & I vs 4 & 2 vs 5 & 3 vs 6 & & & & Average \\
\hline \multirow[t]{2}{*}{ Correlation coefficient } & Xoo & 0.85 & 0.91 & 0.91 & & & & 0.89 \\
\hline & Xoc & 0.65 & 0.77 & 0.67 & & & & 0.70 \\
\hline
\end{tabular}

a Correlation coefficient of Xoo samples.

b Correlation coefficient of Xoc samples. 




Figure 3

Differentially expressed genes by functional category. Functional categories are derived from the primary annotation retrieved from the TIGR Comprehensive Microbial Resource. Black bars indicate $X_{0 o}$ genes and white bars indicate $X o c$ genes.

(5.0\%), DNA metabolism (5.0\%), mobile and extra-chromosomal element functions $(4.3 \%)$, or transport and binding (12.1\%). Xoc genes expressed at a higher level in $\mathrm{XOM} 2$ relative to $\mathrm{PSB}$, as in Xoo, encode hypothetical proteins $(28.6 \%)$ and proteins involved in cellular processes (21.4\%). In contrast to Xoo however, Xoc genes down-regulated in XOM2 predominantly encode proteins involved in protein synthesis $(45.5 \%)$.

Genes for general metabolism and transport and binding proteins Many of the differentially expressed genes in Xoo and Xoc are involved in general metabolism, such as amino acid biosynthesis and energy metabolism. Also several genes for transport and binding proteins are differentially expressed in both strains. Differential expression of these genes likely reflects general adaptation to the different culture media related to nutrient uptake and utilization.

\section{Chemotaxis and bacterial motility}

A number of genes in Xoo and Xoc that are involved in motility and chemotaxis were up-regulated in XOM2 (Additional File 2), for example, in Xoo, chemotaxis genes cheR (XOO1466), encoding a methyl transferase, cheW (XOO1468), encoding a coupling protein, and cheY (XOO2622), encoding a two-component response regulator, and in $X o c$, flagellar basal body and motor switch genes, flgF (XOCORF4434) and fliN (XOCORF4475). The expression of chemoreceptor genes $t s r$ and $m c p$ was upregulated in response to XOM2 in both Xoo and Xoc. The chemoreceptors encoded by these genes perceive environmental chemicals and activate genes such as pil and fli that are involved in movement [31,32]. Consistent with this finding, pil, fli, and another gene involved in bacterial movement, flg, were also up-regulated in XOM2 both in Xoo and Xoc. These data are consistent with the fact that nutrient conditions, especially the type of carbon source, are involved in the regulation of bacterial motility [3135]. Moreover, the abundance of genes involved in bacterial movement that are up-regulated in XOM2 suggests that Xoo and Xoc may activate genes for motility in the nutrient-limited environments of the rice xylem and mesophyll tissue and that these genes may be important for virulence. This notion is supported by the recent report that mutations in genes for twitching motility resulted in reduced virulence in Xoc [36] and by the fact that bacterial chemotaxis has essential roles in virulence in Ralstonia solanacearum [37].

\section{Signal transduction genes}

Two-component systems (TCS) are widespread signal transducers in prokaryotes that enable these organisms to respond to environmental stimuli through changes in gene expression [38]. Environmental cues are typically perceived through a sensor histidine kinase associated with the cell membrane. The second component is a response regulator, which upon activation by the sensor kinase activates downstream components of the response pathway. In many cases, signalling through a single twocomponent system results in a coordinated change in expression of multiple genes [39]. In Xoo, expression of the paired sensor kinase and response regulator genes phoP (XOO0423) and phoQ (XOO0424) is down-regulated in XOM2. phoP-phoQ is a two-component system that governs virulence, mediates the adaptation to $\mathrm{Mg}^{2+}$ limiting environment and regulates numerous cellular activities in Salmonella and other species [40,41]. We showed recently that $p h o P$ and $p h o Q$ in Xoo are required for activation of $h r p$ genes and AvrXa21 activity, and full virulence [42]. Differential expression of phoP-phoQ was not detected in Xoc, raising the possibility that these genes are regulated differently by Xoo and Xoc in planta as well, and therefore may play a role in their distinctive pathogenicity. Another difference was a GGDEF domain protein 
Table 3: Sequences of forward $(F)$ and reverse $(R)$ primers used in semi-quantitative RT-PCR to validate $X o o$ and $X o c$ gene expression changes determined by microarray analysis.

\begin{tabular}{|c|c|}
\hline GenelDa & Primer Sequence \\
\hline XOO4289 & $\begin{array}{l}\text { F 5' ACA TCG CCG ATA ATT TCC AG 3' } \\
\text { R 5' CGC AAC ACC TTG TAC TCG AC 3' }\end{array}$ \\
\hline X004035 & $\begin{array}{l}\text { F 5' GGT CTT CGG ATC GTC AAC AT 3' } \\
\text { R 5' GAT CAG AAA GCC GAT CTT GC 3' }\end{array}$ \\
\hline XOOI994 & $\begin{array}{l}\text { F 5' GTT GGA GCA CAC CAT GAA AG 3' } \\
\text { R 5' GGT ACA GCT CCA GAC CGA TG 3' }\end{array}$ \\
\hline XOO2803 & $\begin{array}{l}\text { F 5' CTG TTC CAA GCA GAC CCT GT 3' } \\
\text { R 5' CAC GAT GGG AAA CCT GAA AC 3' }\end{array}$ \\
\hline XOO0424 & $\begin{array}{l}\text { F 5' CGG CTG AAG AAC TAC GCT TC 3' } \\
\text { R 5' CTT GGT CAG CTC GTT GAT GA 3' }\end{array}$ \\
\hline X000423 & $\begin{array}{l}\text { F 5' CGA AGA AGG CCT CTA CAT GG 3' } \\
\text { R 5' CGA AGA AGG CCT CTA CAT GG 3' }\end{array}$ \\
\hline X000076 & $\begin{array}{l}\text { F 5' GTG CCA CGT TGA AGT CAA GA 3' } \\
\text { R 5' CTC ACT TAA TTC GCG CTT CC } 3^{\prime}\end{array}$ \\
\hline X0OI379 & $\begin{array}{l}\text { F 5' GCG ATA CCA GTC CAG GAT GT 3' } \\
\text { R 5' CTT TTC CTC GTT GCA CTG GT 3' }\end{array}$ \\
\hline XOO0094 & $\begin{array}{l}\text { F 5' CAC CTA CGG CTT TGT CTG GT 3' } \\
\text { R 5' CAT TGC CAA ATG TGT TGG AG 3' }\end{array}$ \\
\hline XОO0770 & $\begin{array}{l}\text { F 5' ATC GGC AGG TCG TAC TTG AT 3' } \\
\text { R 5' GTC AGA CCC TGC TGT TCT CC 3' }\end{array}$ \\
\hline XOO0282 & $\begin{array}{l}\text { F 5' CTG ATG AAT GAG CCT CAC GA 3' } \\
\text { R 5' GAT TCC ATG TAG CCC AGC AT 3' }\end{array}$ \\
\hline XOO2163 & $\begin{array}{l}\text { F 5' AAC GGT AGA ACT TGC CAT CG 3' } \\
\text { R 5' AAC CTG GAC ATC CTG GAC AT 3' }\end{array}$ \\
\hline XOO2757 & $\begin{array}{l}\text { F 5' AGC GCA GTC GCT TAC CTT C 3' } \\
\text { R 5' GCA TAC GAC GAC GAC TAC GA 3' }\end{array}$ \\
\hline X00I664 & $\begin{array}{l}\text { F 5' CAC GCG TCT ACT GGG AAG AT 3' } \\
\text { R 5' AAC ACG TCA TAC AGC GCA TC 3' }\end{array}$ \\
\hline X004468 & $\begin{array}{l}\text { F 5' ACG ATT TCG ACC TGG ACC AC 3' } \\
\text { R 5' ACA AGG ACG CCG AAA AGA T 3' }\end{array}$ \\
\hline XOOI458 & $\begin{array}{l}\text { F 5' CCA GCG TTC CAT CAC TAC G 3' } \\
\text { R 5' AGG GTA ATT AAC CGG CTT CG 3' }\end{array}$ \\
\hline XOCORFI456 & $\begin{array}{l}\text { F 5' AAT GAC AAT GAG GGC ATC AA 3' } \\
\text { R 5' ACT GAT TTG CGT TGT CGT TG 3' }\end{array}$ \\
\hline XOCORF3I44 & $\begin{array}{l}\text { F 5' GCA GAC GTT CGA CAC TTT CA 3' } \\
\text { R 5' GCC TGT GTC TGC GAC TTG TA 3' }\end{array}$ \\
\hline XOCORF3I37 & $\begin{array}{l}\text { F 5' ACG ACC GTA TCC AAC CAG AC 3' } \\
\text { R 5' AAC ATG CTG CGG ATT TCT TC 3' }\end{array}$ \\
\hline XOCORF2869 & $\begin{array}{l}\text { F 5' AGT CGT TCG TAC CAG CCA TC 3' } \\
\text { R 5' GCT CAC CTC CTG CTT GTA GC 3' }\end{array}$ \\
\hline XOCORF0857 & $\begin{array}{l}\text { F 5' GCC AGC TTG AAA GTC AGC TC 3' } \\
\text { R 5' CAT TTG CAG CAT TGG TGA AG 3' }\end{array}$ \\
\hline XOCORF0690 & $\begin{array}{l}\text { F 5' TTC CTT TTC GCC TGG AGT T 3' } \\
\text { R 5' TTC ATC GAC ACC GTC ATT G 3' }\end{array}$ \\
\hline XOCORF4060 & $\begin{array}{l}\text { F 5' AAG TCA GTC CCG GTC AAG GT 3' } \\
\text { R 5' ATT CCT CCA CCA TCT CGT TG 3' }\end{array}$ \\
\hline XOCORF0488 & $\begin{array}{l}\text { F 5' GAC GTT CCG ACC AAT CTG TT 3' } \\
\text { R 5' CTG CCC GAT CTT GAT CAT CT 3' }\end{array}$ \\
\hline XOCORF2820 & $\begin{array}{l}\text { F 5' AAG ACC ACC CAC AAG CTG TT 3' } \\
\text { R 5' GAC CCT TGA TGG TCA GAT CG 3' }\end{array}$ \\
\hline XOCORF4434 & $\begin{array}{l}\text { F 5' AAT CTG GCC AAC GTC GAT AC 3' } \\
\text { R 5' AGC TGG ATC ATT TTC CAC CA } 3^{\prime}\end{array}$ \\
\hline XOCORF0026 & $\begin{array}{l}\text { F 5' ATG GTG GAA AGC CTC AAC AC 3' } \\
\text { R 5' GCC AGG ATA TTG GTC TGG AA 3' }\end{array}$ \\
\hline XOCORF0775 & $\begin{array}{l}\text { F 5' AAA CTC TCG TGC TTG GTG CT 3' } \\
\text { R 5' CAG CGT ATT CGT AGG TGA CG 3' }\end{array}$ \\
\hline XOCORF4022 & $\begin{array}{l}\text { F 5' CAG CAT TCG CTG AAG GAA CT 3' } \\
\text { R 5' AAA TAC GGC ACC TTG TGC TC } 3^{\prime}\end{array}$ \\
\hline XOCORF38I6 & $\begin{array}{l}\text { F 5' TAT ACT GGT CGC TGC TGG TG 3' } \\
\text { R 5' CGG TAA GTC ACC TCG TAG CC 3' }\end{array}$ \\
\hline
\end{tabular}

(XOO2615) down-regulated in XOM2 in Xoo but not in Xoc. Recently, several GGDEF, EAL, and HD-GYP domain proteins of $X$. campestris were shown to play a role in virulence. They are hypothesized to compose a network of signal transduction systems for response to different environmental cues to modulate the level of the second messenger cyclic di-GMP [43].

\section{rax genes (required for $\underline{\text { vrr }} \underline{X}$ a2 I activity)}

We specifically examined expression levels of the rax (required for Avrㅁa21 activity) genes in Xoo and Xoc, and assessed expression of several of these genes independently by RT-PCR (Table 4 ) because AvrXa21 produced by $X o o$ is an important determinant for race-specific interactions and is postulated to be involved in bacterial cell-cell communication [25]. The rax genes are expressed constitutively in rich medium in Xoo [25]. They are highly conserved in Xoo and Xoc, but it is not known whether they are expressed in Xoc and whether Xoc produces AvrXa21. No significant differences in expression of any of the rax genes in Xoo and Xoc greater than 1.75 fold were observed in the microarray data, and the RT-PCR results confirmed this observation, except for Xoo raxC which showed a slight down regulation in XOM2. These results suggest that the expression of $\operatorname{rax}$ genes is largely unaffected by nutrient status. Their expression in Xoc raises the possibility that like Xoo, Xoc produces AvrXa21 or a similar molecule.

hrp genes (hypersensitive reaction and pathogenicity)

We also examined expression of hrp genes, which as described above, are essential for pathogenicity in both Xoo and Xoc. Expression of Xoo hpa1 (XOO0095), hrpG (XOO1379), hrcC (XOO0094), and hrpE (XOO0076) were up-regulated in XOM2, consistent with the report by Tsuge et al. [18] which showed that several $h r p$ loci in Xoo strain T7174 are induced in XOM2. No other Xoo hrp genes represented on the array showed induction greater than 1.75 fold in XOM2. However, when several were examined by semi-quantitative RT-PCR each was detectably up-regulated (Table 4). The Tsuge et al. study reported $>200$ fold induction for some hrp genes in XOM2. It should be noted, however, that the authors used a GUS reporter, and therefore measured accumulated enzyme activity, which does not necessarily correlate quantitatively with microarray results, which measure accumulation of mRNA. Also, there may be differences in the response of the two strains, T7174 and PXO99A, used here, to XOM2. Clearly though, semi-quantitative RT-PCR appears to have been a more sensitive assay for some of the hrp genes represented on the array. In stark contrast to the results with Xoo, in Xoc, expression increase of greater than 1.75 fold in XOM2 in the microarray experiment was only observed for $h p a 1$ (XOCORF2625). Upregulation was not detected for any of several Xoc hrp genes tested by semi-quantitative RT-PCR with the exception of $h r p E$, for 
Table 3: Sequences of forward (F) and reverse (R) primers used in semi-quantitative RT-PCR to validate $X o 0$ and Xoc gene expression changes determined by microarray analysis.

\begin{tabular}{ll}
\hline XOCORFI384 & F 5' CCA AGA TCC GCA AGA AGA AG 3' \\
& R 5' GGA TCA GCT TTT CGA TCT GC 3' \\
XOCORF2448 & F 5' GCT CAC TTA ATT CGC GCT TC 3' \\
& R 5' AAC GAG CTG CTT AGC GTT GT 3'
\end{tabular}

aThe gene ID is according to the primary annotation obtained from the Comprehensive Microbial Resource. XOO designations represent IDs of genes from Xanthomonas oryzae pv. oryzae KACC I033I and XOCORF designations represent IDs of genes from Xanthomonas oryzae pv. oryzicola BLS256.

which increased expression in XOM2 was detectable by this method. Xiao et al [44], using RT-PCR, observed hpa1 expression in strain RS105 of Xoc in a synthetic medium they named XOM3, but not in nutrient broth (NB). XOM3 is identical to XOM2 except that it substitutes $\mathrm{Fe}(\mathrm{II})$-EDTA for $\mathrm{Fe}(\mathrm{III})$-EDTA. The authors also reported expression of the $g f p$ gene cloned downstream of the $h r p X$ promoter in cultures grown in XOM3 but not NB. The reporter construct itself was positioned downstream of the lac promoter, so this finding is difficult to interpret, but may indicate a difference in $h r p$ regulation between RS105 and BLS256, the strain used here. Unfortunately, no other hrp genes were tested in RS105.
Our observation that, in Xoc cultured in XOM2, hrp genes other than $h p a 1$ and $h r p E$, were not induced, including genes encoding the key Hrp regulators $\mathrm{HrpG}$, a member of the OmpR family of response regulators of two-component systems [45], and HrpX, an AraC-type transcriptional activator that is the target of HrpG [46] underscores the fact that $h r p$ genes are regulated differently in Xoo vs. Xoc, and reveals that the differences reside at or upstream of $h r p G$, perhaps at the level of environmental sensing. This in vitro finding in turn suggests that $h r p$ gene expression may differ for these pathogens in in planta environments (e.g., the xylem and the mesophyll apolast), an exciting possibility that remains to be tested, and that may provide clues to tissue specificity.

The fact that Xoc hpa1 and hrpE are induced in XOM2, despite lack of induction of $h r p G, h r p X$, and other $h r p$ genes, indicates that $h p a 1$ and $h r p E$ are under different or additional regulatory controls from the other $h r p$ genes. Curiously, both genes encode extracellular proteins. HrpE is the main structural component of the hrp pilus [47], and Hpa 1 is a Hrp-secreted protein with similarity to harpins [48], glycine-rich proteins that may assist in type III delivery of effectors into plant cells [49]. The differential regulation we have detected here for $h p a 1$ and $h r p E$

Table 4: Expression profiles of hrp and rax genes in Xoo and Xoc cultured in XOM2 vs. PSB by microarray and semi-quantitative RTPCR analysis

\begin{tabular}{|c|c|c|c|c|c|c|c|c|c|}
\hline Locus ID & Product & $P$-value ${ }^{a}$ & Log2 ratioa & RT-PCR ${ }^{b}$ & Locus ID & Product & P-value ${ }^{a}$ & Log2 ratio ${ }^{a}$ & RT-PCR \\
\hline X000095 & hpal & 0 & 1.529 & & XOCORF 2625 & hpal & 0.000307 & 1.219 & \\
\hline XOOI379 & hrpG & I.5E-09 & 1.102 & + & XOCORF3400 & $h r p G$ & 0.025035 & 0.086 & 0 \\
\hline X000094 & hrcC & $2.9 \mathrm{E}-1 \mathrm{I}$ & 1.094 & + & XOCORF2442 & hpaF & 0.011623 & 0.019 & \\
\hline X000076 & $h r p E$ & I.IE-II & 0.974 & + & XOCORF2448 & hrpE & 0.010426 & 0.757 & + \\
\hline XOOI380 & hrpX & 0.000154 & 0.410 & + & XOCORF3402 & $h r p X$ & 0.0822 & -0.443 & 0 \\
\hline X000085 & hrcU & 3.IE-06 & 0.313 & + & XOCORF2466 & hpa2 & 0.099664 & -0.064 & \\
\hline X000090 & hrpB5 & 0.345847 & 0.076 & & XOCORF245I & hrcS & 0.000253 & 0.003 & \\
\hline X004533 & $h r p B$ & 0.222464 & 0.063 & + & XOCORF2289 & $h r p B$ & $0.06354 I$ & 0.073 & 0 \\
\hline X000087 & hrpB2 & 0.411161 & 0.057 & & XOCORF2457 & hrpB2 & 0.119757 & 0.013 & 0 \\
\hline X000075 & hpaB & 0.444516 & 0.041 & & XOCORF2447 & hpaB & 0.029266 & 0.194 & \\
\hline X000066 & hrpF & 0.792649 & -0.019 & + & XOCORF2444 & hrpF & 0.077523 & 0.036 & 0 \\
\hline X000079 & hpaA & 0.199054 & -0.070 & + & XOCORF2458 & hrpB3 & 0.056872 & 0.026 & \\
\hline X000077 & hrpD6 & 0.252583 & -0.073 & + & XOCORF2449 & hrpD6 & 0.049163 & -0.093 & \\
\hline X000089 & hrpB4 & 0.01751 & -0.152 & & XOCORF2459 & hrpB4 & 0.45174 & -0.038 & \\
\hline X000091 & $\operatorname{hrcN}$ & 4.IE-05 & -0.196 & & XOCORF2462 & hrpB7 & 0.039424 & -0.237 & \\
\hline X000083 & hpaP & 0.004091 & -0.202 & & XOCORF2454 & hpaP & 0.061767 & -0.008 & \\
\hline X003396 & $\operatorname{rax} Q$ & 0.407272 & -0.038 & & XOCORF3280 & $\operatorname{rax} Q$ & 0.045558 & 0.088 & 0 \\
\hline X0O3544 & $\operatorname{rax} A$ & 0.807527 & -0.014 & 0 & XOCORFI002 & $\operatorname{rax} A$ & 0.274492 & 0.057 & \\
\hline X003535 & $\operatorname{rax} R$ & 0.418945 & 0.056 & & XOCORF0993 & $\operatorname{rax} R$ & 0.786683 & 0.015 & 0 \\
\hline X003397 & $\operatorname{rax} P$ & 0.000764 & 0.183 & 0 & XOCORF3279 & $\operatorname{rax} P$ & 0.014682 & -0.018 & 0 \\
\hline X0O3534 & $\mathrm{raxH}$ & 0.001411 & -0.191 & & XOCORF0994 & $\mathrm{raxH}$ & 0.319727 & -0.054 & \\
\hline X000927 & $\operatorname{rax} C$ & 0.001717 & -0.352 & - & XOCORF3I27 & $\operatorname{rax} C$ & 0.123998 & -0.162 & 0 \\
\hline X003545 & $\operatorname{rax} S T$ & $4.2 \mathrm{E}-05$ & -0.288 & 0 & & & & & \\
\hline X0O3543 & $\operatorname{rax} B$ & 0.422388 & $-0.05 I$ & 0 & & & & & \\
\hline
\end{tabular}

aResults of microarray analysis, as described in text. A $\log 2$ ratio of 0.8 is equivalent to a 1.75 fold relative increase in expression.

aResults of RT-PCR, as described in text. +, up-regulated in XOM2; -, down-regulated in XOM2; 0 , no change in transcript abundance detected, blank, not tested. 
may reflect differential regulation in planta. This possibility fosters the intriguing speculation that the corresponding proteins accumulate early in the plant-bacterial interaction for rapid deployment once the rest of the type III secretion apparatus is assembled.

Tsuge et al (2006) [19] demonstrated that induction of $h r p G$ in XOM2 was partially dependent on the trh (transcriptional regulator of $\underline{h r p}$ ) gene, and that trh was also required for wildtype levels of $h p a 1$ expression in planta, but that trh mutation did not result in a measurable difference in virulence. In light of our uncoupling of hpa1 and hrp expression in Xoc, it may be informative to assay the effect of the trh mutation in Xoo on the expression of other hrp genes in planta. Clearly, however, the possibility of multiple pathways for activation of hrp gene expression under different conditions exists.

\section{Conclusion}

In contrast to other large scale approaches to the study of gene expression in plant pathogenic bacteria, including cDNA-AFLP [50] and in vivo expression technology (IVET, [51-53]), the whole genome microarray allows for genome-wide profiling of transcript levels under different conditions and over time. Cost, flexibility, sensitivity, and specificity are important factors that affect the utility of an array. In this study, we designed and constructed a microarray for Xoo and Xoc based on spotted 50-70-mer oligonucleotides. This platform is a relatively low cost and flexible, with good sensitivity [54]. Using the PICKY software, we were able to maximize specificity of probes on the array.

Our initial experiments with the Xo array and validation of select gene expression values by semi-quantitative RTPCR demonstrate that the array generates robust and reliable data, though it may not be as sensitive as RT-PCR for some genes. By comparing gene expression in Xoo and Xoc cultured in PSB vs. XOM2, these experiments also provide insight and prompt new hypotheses regarding differential regulation of genes between Xoo and Xoc that may contribute to their distinct pathogenic characteristics. It is important to note that the artificial minimal medium XOM2 cannot be presumed to be an accurate proxy for in planta conditions. For example, although we have demonstrated that the component(s) or properties of XOM2 that induce in vitro hrp gene expression in Xoo are not effective for Xoc, it is not clear whether these component(s) or properties are the same as those that induce Xoo hrp gene expression in planta, or whether in fact Xoo and Xoc respond to different, or identical, cues in the host. Nonetheless, the results presented provide several candidate genes whose expression it will be important to compare in planta, and whose regulation it will be important to elucidate, toward gaining a detailed understanding of Xoo and Xoc pathogenicity that can then be used to develop more effective and environmentally-sound disease management practices.

\section{Methods}

\section{Bacterial strains, growth conditions, and media}

Xanthomonas oryzae pv. oryzae strain PXO99A (Philippine race 6 provided by Jan Leach) and X. oryzae pv. oryzicola strain BLS256 were used for these experiments. Cells were grown at $28^{\circ} \mathrm{C}$ with shaking at $200 \mathrm{rpm}$, in nutrient-rich PSB (10 g/liter of peptone, $10 \mathrm{~g} /$ liter of sucrose, $1 \mathrm{~g} /$ liter of L-glutamic acid, monosodium salt; [28]). For experiments testing the effects of the modified minimal medium, XOM2, bacterial cells were cultured in PSB until OD600 equaled 0.2 , washed twice, and then immediately transferred into XOM2 for $16 \mathrm{hrs}$. XOM2 [18] consists of $0.18 \%$ xylose sugar, $670 \mu \mathrm{M} \mathrm{D}$, L-methionine, $10 \mathrm{mM}$ sodium L(+)-glutamate, $14.7 \mathrm{mM} \quad \mathrm{KH}_{2} \mathrm{PO}_{4}, 40 \mu \mathrm{M}$ $\mathrm{MnSO}_{4}, 240 \mu \mathrm{M} \mathrm{Fe}(\mathrm{III})$. EDTA and $5 \mathrm{mM} \mathrm{MgCl}_{2}, \mathrm{pH}$ 6.5. Cells were washed twice prior to being harvested.

\section{RNA preparation}

RNA was isolated using TRIzol $^{\circledast}$ reagent (Invitrogen, Carlsbad, CA, U.S.A.). The RNA samples were treated with 10 units of DNaseI (Invitrogen, Carlsbad, CA, U.S.A) for $30 \mathrm{~min}$ at room temperature, followed by column purification using the RNeasy midi kit (Qiagen, Germantown, $\mathrm{MD}$, U.S.A.). The quality of RNA was determined by carrying out gel electrophoresis on a $1 \%$ agarose gel and was verified visually by using an Agilent 2100 Bioanalyzer (Agilent Technologies, Santa Clara, CA, U.S.A.). The quantity of total RNA was determined by measuring the absorbance at $260 \mathrm{~nm}$ and $280 \mathrm{~nm}$. In addition, the level of protein contamination in the RNA was measured by using A260/A280 ratio.

\section{cDNA generation and labeling}

cDNA was generated by using SuperScript ${ }^{\mathrm{TM}}$ III First-Strand kit and following the manufacturer's protocol (Invitrogen, Carlsbad, CA, U.S.A.). Twenty micrograms of high quality RNA was used mixed with random hexamers that were used as primers for $\mathrm{CDNA}$ generation and the mixture then preheated at $70^{\circ} \mathrm{C}$ for 15 mins. Primers were annealed to total RNA and extended with a labeling mixture consisting of $6.0 \mu \mathrm{l}$ of $5 \times$ buffer, $2.0 \mu \mathrm{l}$ of $0.1 \mathrm{M} \mathrm{DTT}, 1.0 \mu \mathrm{l}$ of RNasin, $2.0 \mu \mathrm{l}$ of SuperScript III reverse transcriptase, $2.0 \mu \mathrm{l}$ of $25 \times$ dNTP-allyl-amino (aa) dUTP mixture (final concentration $0.5 \mathrm{mM}$ each of dATP, CCTP, and dGTP, $0.35 \mathrm{mM}$ aa-dUTP, $0.15 \mathrm{mM}$ dTTP) at $25^{\circ} \mathrm{C}$ for $10 \mathrm{~min}$ followed by $2 \mathrm{~h}$ at $42^{\circ} \mathrm{C}$. The RNA template was hydrolyzed using $3 \mu \mathrm{l}$ of $2.5 \mathrm{~N} \mathrm{NaOH}\left(37^{\circ} \mathrm{C}, 15 \mathrm{~min}\right)$ followed by neutralization with $15 \mu \mathrm{l}$ of $2 \mathrm{M}$ HEPES. Unincorporated primers and nucleotides were removed using the Zymo research kit according to the manufacturer's protocol (Zymo research, Genetix, UK) and the purified amino allyl-modified cDNA was resuspended in $60 \mu \mathrm{l}$ of $50 \mathrm{mM}$ sodium 
bicarbonate ( $\mathrm{pH}$ 9.0). The amino allyl-modified cDNA was used to resuspend lyophilized Cy3 or Cy5 and incubated for $1 \mathrm{hr}$ at room temperature in the dark. The reaction was quenched by adding $15 \mu \mathrm{l}$ of $4 \mathrm{M}$ hydroxylamine (15 min, room temperature in the dark). The dye-coupled cDNA was then purified by using the Zymo research kit (Zymo research, Genetix, UK).

\section{Oligo design}

Our goal was to design a complete set of oligos that would uniformly detect gene-specific expression patterns for both Xoo and Xoc. To achieve the highest standard of uniformity, sensitivity and specificity for the Xo array it was necessary to utilize an optimized oligo design software that integrates the whole Xo gene set in its computation instead of considering each gene individually in a batch design mode. The Xo array carries 2 copies of the combined oligonucleotide set chosen by PICKY, the most efficient software developed to date, for this task [55].

The combined oligo set was designed based on the following steps, using PICKY for each oligo selection step: 1) The gene sets of Xoo and Xoc were combined with an additional hygromycin phosphotransferase gene and given to PICKY as a whole to design the shared oligos, i.e., oligos that can target at least one Xoo and one Xoc gene; 2) Xoo and Xoc genes targeted by the chosen shared oligos were removed from their individual gene sets and served as the second round design nontargets, i.e., genes that should be avoided by any PICKY designed oligo; 3 ) PICKY was then used to design oligos that can identify the remaining Xoo genes, using the earlier removed Xoo genes and the hygromycin phosphotransferase gene as nontargets; 4) Similarly, PICKY was used again to design oligos that can identify the remaining Xoc genes, using the removed Xoc genes and the hygromycin phosphotransferase gene as nontargets; 5) Finally, all oligos designed in steps 1, 3 and 4 were merged together to form the combined 4,675 oligo set.

Genome sequences and primary annotation of Xoo and Xoc were retrieved from the Comprehensive Microbial Resource [5] version 2.3 on December 22, 2005. The annotation is provided as Additional files 5 and 6. For Xoo KACC10331, these data are also available from the NCBI GenBank, under accession NC 006834. For Xoc BLS256, the finished genome sequence is also available from the NCBI Genbank, under accession AAQN01000001, but at the time of writing, the annotation has not yet been accessioned in that database.

\section{Oligo synthesis}

Oligos used for spotting were synthesized by Integrated DNA Technology [56]. As a control, an oligo was designed by PICKY to detect $h$ ph but not Xo genes. This control was included in 2 well positions on each 384-well oligo synthesis plate except the last plate, which had only one $h p h$ position. Because the positions of this control were randomized across plates, the oligo also served as a check for array printing when labelled and hybridized against the array.

\section{Spotting}

Microarrays were prepared at the ArrayCore Microarray Facility at the University of California, Davis [57]. Oligonucleotides were suspended in $1 \times$ Nexterion Spot solution at a final concentration of $20 \mu \mathrm{M}$ and spotted onto aminosilane coated glass slides (Schott-Nexterion, USA). Oligonucleotides were spotted using a Lucidea Array Spotter (Amersham) in a humidity controlled spotting chamber $(70 \%)$ at room temperature. Microarrays were deposited using $190 \mu \mathrm{m}$ column and row pitches, and spot diameters averaged $80 \mu \mathrm{m}$ under these conditions. After spotting, slides were allowed to sit at $70 \%$ humidity overnight at room temperature to maximize oligo binding. Microarrays were allowed to dry at ambient conditions and stored in the dark under argon at room temperature until use. Slides and spotting plates were tracked using the array spotter's built-in barcode reader and the information was used to generate the gene array layout file of the spotted $5 \mathrm{k}$ Xo oligonucleotide microarray.

\section{Amino-blocking pre-treatment}

Prior to the hybridization process, oligo-spotted slides were pre-treated with a blocking step that removes unbound DNA-molecules and buffer substances from the slides by extensive washing in order to avoid any interference with subsequent hybridization experiments. Spotted slides were incubated in amino blocking solution ( $5 \mathrm{~g}$ succinic anhydride in $315 \mathrm{ml} \mathrm{n}$-methylpyrrolidone, $35 \mathrm{ml} 0.2$ $\mathrm{M}$ sodium borate $\mathrm{pH}$ 8.0) at room temperature for 15 mins. Slides were placed in $0.1 \%$ SDS solution $20 \mathrm{sec}$ and washed with nanopure water $20 \mathrm{sec}$ two times and then were transferred into the sodium borohydride block solution to undergo a sodium borohydride pre-treatment.

\section{Sodium borohydride pre-treatment}

To minimize non-specific autofluorescence from the spotted material [58], slides were placed into a block solution containing $2 \times$ SSC, $0.05 \%$ SDS, $0.25 \% \mathrm{NaBH}_{4}$ (Biochemical Technologies, USA) and incubated at $42{ }^{\circ} \mathrm{C}$ for 20 min. Slides were transferred to $1 \times$ SSC for $5 \mathrm{~min}$ at room temperature and then sequentially washed with vigorous stirring using fresh $1 \times \operatorname{SSC}(3 \times 5 \mathrm{~min}$, room temperature $)$, $0.2 \times \operatorname{SSC}(4 \times 2 \mathrm{~min}$, room temperature), and Nanopure water $(1 \times 2 \mathrm{~min}$, room temperature). Slides were spindried (1000 rpm, $10 \mathrm{~min})$ and stored under argon until use. 


\section{Hybridization and scanning}

Labeled probes were evaporated in a vacuum centrifuge on aqueous setting at $60^{\circ} \mathrm{C}$ to a volume of approximately 2-3 $\mu$ l. Evaporated probes were then resuspended in 100 $\mu \mathrm{l}$ of a salt based hybridization solution (Ocimum Biosolutions) at room temperature. All hybridization and scanning steps were performed in a hepa and carbon filtered clean room at the ArrayCore Microarray Facility at University of California, Davis [57]. Hybridization occurred on a Tecan HS 4800 hybridization station. To block non-specific hybridization, a pre-hyridization buffer $(5 \times$ SSPE, 6 M Urea, $0.5 \%$ Tween-20, 10× Denhardt's solution) was applied to the slides at $50^{\circ} \mathrm{C}$ and agitated for 15 minutes on the medium setting. Labeled probes were denatured by heating the mixture at $95^{\circ} \mathrm{C}$ for 3 mins and then snapcooling on ice for 30 seconds. Probes were applied into the injector to hybridize with printed slides. Samples were hybridized for 16 hours at $42^{\circ} \mathrm{C}$, Following hybridization, the slides were consecutively washed at $37^{\circ} \mathrm{C}$ with three salt based buffers of increasing stringency $(2 \times \mathrm{SSC}$, $0.1 \%$ SDS, $1.0 \times$ SSC, and $0.5 \times$ SSC). Each buffer wash step was repeated twice, with a soak time of one minute followed by a one minute wash. A final wash step with water was performed. Following the final wash, slides were dried under a constant stream of $\mathrm{N}_{2}$ at $30^{\circ} \mathrm{C}$. Slides were kept under $\mathrm{N}_{2}$ until scanning.

\section{Capture of raw data}

Hybridized microarray slides were imaged using a GenePix 4000B dual laser microarray scanner (Axon Instruments, USA) at $5 \mu \mathrm{m}$ resolution. Slides were imaged using $100 \%$ laser power for both lasers (532 $\mathrm{nm}$ and $635 \mathrm{~nm}$ ) and scanned twice using the high PMT and low PMT settings. All images were processed using GenePix software (Axon Instruments, USA) for element identification and quantification. The metadata associated with the hybridizations, along with the "raw" intensities obtained from the GenePix quantitation.

Validation of expression patterns of candidate genes using semi-quantitative $R T-P C R$ and quantitative $R T-P C R$

For the first-strand cDNA synthesis, $100 \mathrm{ng}$ of mRNA was reverse-transcribed in a total volume of $20 \mu \mathrm{l}$ that contained $50 \mathrm{ng}$ of random hexamer, $2.5 \mathrm{mM}$ dNTP, 40 unit of RNaseOUT ${ }^{\mathrm{TM}}$, and 200 units of SuperScript ${ }^{\mathrm{TM}}$ III reverse transcriptase (the latter two components from Invitrogen, Carlsbad, CA) in reaction buffer supplied by the manufacturer. The reaction mixtures were incubated in $25^{\circ} \mathrm{C}$ for $10 \mathrm{~min}$, then $4^{\circ} \mathrm{C}$ for $60 \mathrm{~min}$. PCRs were performed in 50 $\mu \mathrm{l}$ reactions (containing $0.1 \mu \mathrm{l}$ aliquots of the respective cDNA reaction mixture, $0.2 \mu \mathrm{M}$ of gene-specific primers, $10 \mathrm{mM}$ dNTPs, 1 unit of Taq DNA polymerase (Invitrogen), and $10 \times$ Taq buffer supplied by the manufacturer). Each reaction included an initial 5-min denaturation at $94^{\circ} \mathrm{C}$, followed by 22 to 30 cycles of PCR $\left(94^{\circ} \mathrm{C}, 45 \mathrm{sec}\right.$; $60^{\circ} \mathrm{C}, 45 \mathrm{sec} ; 72^{\circ} \mathrm{C}, 45 \mathrm{sec}$ ), and a final $10 \mathrm{~min}$ at $72^{\circ} \mathrm{C}$. Afterward, $20 \mu \mathrm{l}$ of each reaction mixture was separated on a $1.0 \%$ agarose gel. (The primers used for semi-quantitative RT-PCR are described in Table 3). 16S ribosomal RNAs was used as controls for semi-quantitative RT-PCR. Primer sets used for semi-quantitative RT-PCR were designed using Primer3 [59]. Sequences of the primers used are shown in Table 3. Visualized band intensities of semi-quantitative RT-PCR products on the EtBr-stained agarose gels were transformed to digital values using Totallab TL100 software (Nonlinear Dynamics Ltd.). Log2 transformation was applied to digital band intensity values using the same mathematic transformation equations that had been applied to the microarray data. Fold changes from the microarray experiments were plotted against those from the semi-quantitative RT-PCR experiments.

For quantitative RT-PCR, cDNA generated as described in semi-quantitative RT-PCR was used as template for quantitative RT-PCR. Five Xoo and 2 Xoc genes were tested by using $50 \mu \mathrm{l}$ reaction mixed with SYBR $^{\circledR}$ Green PCR Master Mix kit (Applied Biosystems, CA, USA.) and following the protocol as provided by manufacturer. Each reaction included an initial ramping $2 \mathrm{~min} 50^{\circ} \mathrm{C}$, activation 10 mins $95^{\circ} \mathrm{C}$, and then followed by 40 cycles of PCR $\left(95^{\circ} \mathrm{C}\right.$, $\left.15 \mathrm{sec} ; 60^{\circ} \mathrm{C}, 60 \mathrm{sec}\right)$. The amount of Xoo and Xoc tested genes from PSB and XOM2 cultures were quantitated by calculating from each corresponding standard curves.

\section{Accession numbers}

All of the microarray data have been deposited in the National Center for Biotechnology Information Gene Expression Omnibus (GEO) under accession number GSE 9658.

\section{Competing interests}

The authors declare that they have no competing interests.

\section{Authors' contributions}

$\mathrm{Y}-\mathrm{SS}, \mathrm{MS}, \mathrm{AB}, \mathrm{PR}$ designed the research project. Y-SS, YL, $\mathrm{K}-\mathrm{HJ}, \mathrm{HHC}$ constructed the microarray. MS, LW, Y-SS, JP${ }^{1}$ prepared samples for microarray studies. MS, Y-SS, JP3, $\mathrm{JP}^{1}$ performed the microarray experiments. Y-SS, MS analyzed microarray data. Y-SS, MS, LW, JP5, HC, AB, PR drafted the manuscript.

\section{Additional material}

\section{Additional file 1}

Error rate for Xo microarray hybridized with labeled cDNA derived from Xoo or Xoc RNA using a heterologous gene (hph) and empty spots. Click here for file

[http://www.biomedcentral.com/content/supplementary/14712180-8-99-S1.doc] 


\section{Additional file 2}

Xoo and Xoc genes differentially expressed in XOM2 relative to PSB by microarray analysis using a false discovery rate of 5\% and a fold-change minimum of 1.75 (log2ratio 0.8 ).

Click here for file

[http://www.biomedcentral.com/content/supplementary/14712180-8-99-S2.doc]

\section{Additional file 3}

Validation of microarray results using semi-quantitative RT-PCR. $16 \mathrm{~s}$ $r D N A$ (16sDNA) was used as a control. The log2 ratios are shown for the expression of 16 select genes in Xoo (A) and Xoc (B) cultured in XOM2 $(X)$ vs. PSB (P), calculated based on densitometry of products separated by agarose gel electrophoresis and visualized by ethidium bromide staining.

Click here for file

[http://www.biomedcentral.com/content/supplementary/1471-

2180-8-99-S3.tiff]

\section{Additional file 4}

Validation of microarray results using quantitative RT-PCR. Relative transcript levels of five Xoo (A) and two Xoc (B) genes in PSB vs. XOM2 culture were quantified with reference to corresponding standard curves and plotted as ng PCR product. The primers used are noted below each plot.

Click here for file

[http://www.biomedcentral.com/content/supplementary/14712180-8-99-S4.png]

\section{Additional file 5}

Xanthomonas oryzae $p v$. oryzae KACC10331 primary annotation retrieved from the public Comprehensive Microbial Resource version 2.3 on December 22, 2005.

Click here for file

[http://www.biomedcentral.com/content/supplementary/14712180-8-99-S5.xls]

\section{Additional file 6}

Xanthomonas oryzae $p v$. oryzicola BLS256 primary annotation retrieved from the public Comprehensive Microbial Resource version 2.3 on December 22, 2005.

Click here for file

[http://www.biomedcentral.com/content/supplementary/14712180-8-99-S6.xls]

\section{Acknowledgements}

The authors thank David O. Niño-Liu and Damien Meyer for critical reading of the manuscript. This research was funded in part by competitive grants from the National Science Foundation Plant Genome Program (award \#DBI03 13887 to PR and award \#0227357 to AB) and from NIH GM 59942 and USDA grant 2006-01 888 to PR. MS was partially supported by a Thai Government Scholarship and a Jastro-Shields Grant (2007-2008) from the University of California, Davis.

\section{References}

I. Niño-Liu DO, Ronald PC, Bogdanove A): Xanthomonas oryzae pathovars: model pathogens of a model crop. Molecular Plant Pathology 2006, 7:303-324.

2. Ou S: Rice disease. 2nd edition. Commonwealth Agricultural Bureau, Kew, Surrey; 1985.
3. Ochiai H, Inoue Y, Takeya M, Sasaki A, Kaku H: Genome sequence of Xanthomonas oryzae pv. oryzae suggests contribution of large numbers of effector genes and insertion sequences to its race diversity. Jpn Agri Res Quart 2005, 39:275-287.

4. Lee BM, Park YJ, Park DS, Kang HW, Kim JG, Song ES, Park IC, Yoon UH, Hahn JH, Koo BS, Lee GB, Kim H, Park HS, Yoon KO, Kim JH, Jung $\mathrm{C}$, Koh NH, Seo JS, Go SJ: The genome sequence of Xanthomonas oryzae pathovar oryzae KACCI 033 I, the bacterial blight pathogen of rice. Nucleic Acids Res 2005, 33(2):577-586.

5. Comprehensive Microbial Resource [http://cmr.jcvi.org/tigrscripts/CMR/CmrHomePage.cgi]

6. Duggan DJ, Bittner M, Chen Y, Meltzer P, Trent JM: Expression profiling using cDNA microarrays. Nature genetics 1999, 2I(I Suppl): $10-14$.

7. Hughes TR, Mao M, Jones AR, Burchard J, Marton MJ, Shannon KW Lefkowitz SM, Ziman M, Schelter JM, Meyer MR, Kobayashi S, Davis C, Dai H, He YD, Stephaniants SB, Cavet G, Walker WL, West A, Coffey E, Shoemaker DD, Stoughton R, Blanchard AP, Friend SH, Linsley PS: Expression profiling using microarrays fabricated by an ink-jet oligonucleotide synthesizer. Nature biotechnology 200I, I 9(4):342-347.

8. DeRisi JL, lyer VR, Brown PO: Exploring the metabolic and genetic control of gene expression on a genomic scale. Science 1997, 278:680-686.

9. Hauser NC, Vingron M, Scheideler M, Krems B, Hellmuth K, Entian $K D$, Hoheisel JD: Transcriptional profiling on all open reading frames of Saccharomyces cerevisiae. Yeast (Chichester, England) 1998, I 4(I 3): I209-1221.

10. Astua-Monge G, Freitas-Astua J, Bacocina G, Roncoletta J, Carvalho SA, Machado MA: Expression profiling of virulence and pathogenicity genes of Xanthomonas axonopodis pv. citri. Journal of bacteriology 2005, I87(3): | 20I-I 205.

II. Guidot A, Prior P, Schoenfeld J, Carrere S, Genin S, Boucher C: Genomic structure and phylogeny of the plant pathogen Ralstonia solanacearum inferred from gene distribution analysis. Journal of bacteriology 2007, I89(2):377-387.

12. He YW, Xu M, Lin K, Ng YJ, Wen CM, Wang LH, Liu ZD, Zhang HB, Dong YH, Dow JM, Zhang LH: Genome scale analysis of diffusible signal factor regulon in Xanthomonas campestris pv. campestris: identification of novel cell-cell communicationdependent genes and functions. Molecular microbiology 2006, 59(2):610-622.

13. Koide T, Vencio RZ, Gomes SL: Global gene expression analysis of the heat shock response in the phytopathogen Xylella fastidiosa. Journal of bacteriology 2006, 188(16):582I-5830.

14. Lu SE, Wang N, Wang J, Chen ZJ, Gross DC: Oligonucleotide microarray analysis of the salA regulon controlling phytotoxin production by Pseudomonas syringae pv. syringae. Mol Plant Microbe Interact 2005, I 8(4):324-333.

15. Valls M, Genin S, Boucher C: Integrated regulation of the type III secretion system and other virulence determinants in Ralstonia solanacearum. PLoS pathogens 2006, 2(8):e82.

16. Wang N, Lu SE, Wang J, Chen ZJ, Gross DC: The expression of genes encoding lipodepsipeptide phytotoxins by Pseudomonas syringae pv. syringae is coordinated in response to plant signal molecules. Mol Plant Microbe Interact 2006, 19(3):257-269.

17. He YQ, Zhang L, Jiang BL, Zhang ZC, Xu RQ, Tang DJ, Qin J, Jiang W, Zhang X, Liao J, Cao JR, Zhang SS, Liang XX, Wei ML, Lu GT, Feng JX, Chen B, Cheng J, Tang JL: Comparative and functional genomics reveals genetic diversity and determinants of host specificity among reference strains and a large collection of Chinese isolates of the phytopathogen Xanthomonas campestris pv. campestris. Genome Biol 2007, 8( I0):R2।8.

18. Tsuge S, Ayako F, Rie F, Takashi OKU, Kazunori T, Hirokazu O, Yasuhiro I, Hisatoshi K, Yasuyuki K: Expression of Xanthomonas oryzae pv. oryzae hrp Genes in XOM2, a Novel Synthetic Medium. J Gen Plant Path 2002, V68(4):363.

19. Tsuge S, Nakayama T, Terashima S, Ochiai H, Furutani A, Oku T, Tsuno K, Kubo Y, Kaku H: Gene involved in transcriptional activation of the hrp regulatory gene hrpG in Xanthomonas oryzae pv. oryzae. Journal of bacteriology 2006, I88(II):4I58-4I62.

20. Schulte R, Bonas U: A Xanthomonas Pathogenicity Locus Is Induced by Sucrose and Sulfur-Containing Amino Acids. Plant Cell 1992, 4(I):79-86. 
21. Makino S Sugio, A., White, F.F., and Bogdanove, A.J.: Inhibition of resistance gene mediated defense in rice by Xanthomonas oryzae pv. oryzicola. Mol Plant-Microbe Interact 2006, 19:240-249.

22. Zhu W MaGbanua, M., and White, F.: Identification of two nove hrp-associated genes in the hrp gene cluster of Xanthomonas oryzae pv. oryzae. J Bacteriol 2000, I 82(7): |844-|853.

23. Rahme LG, Mindrinos MN, Panopoulos NJ: Plant and environmental sensory signals control the expression of hrp genes in Pseudomonas syringae pv. phaseolicola. Journal of bacteriology 1992, I 74(I I):3499-3507.

24. Wei ZM Sneath, B. J., Beer, S. V.: Expression of Erwinia amylovora hrp genes in response to environmental stimuli. I Bacteriol 1992, I 74: 1875-1882

25. Lee SW, Han SW, Bartley LE, Ronald PC: Unique characteristics of Xanthomonas oryzae pv. oryzae AvrXa2l and implications for plant innate immunity. PNAS 2006, 103(49): 18395-18400.

26. Burdman S, Shen Y, Lee SW, Xue Q, Ronald P: RaxH/RaxR: a twocomponent regulatory system in Xanthomonas oryzae pv. oryzae required for AvrXa2 I activity. Mol Plant Microbe Interact 2004, I7(6):602-612.

27. da Silva FG, Shen Y, Dardick C, Burdman S, Yadav RC, de Leon AL, Ronald PC: Bacterial genes involved in type I secretion and sulfation are required to elicit the rice $\mathrm{Xa2l}$-mediated innate immune response. Molecular Plant-Microbe Interactions 2004, I 7(6):593-60I.

28. Shen $Y$, Sharma P, da Silva FG, Ronald PC: The Xanthomonas oryzae pv. oryzae raxP and raxQ genes encode an ATP sulfurylase and adenosine-5'-phosphosulphate kinase that are required for AvrXa2I avirulence activity. Mol Microbiol 2002, 44:37-38.

29. Rocke DM: Design and analysis of experiments with high throughput biological assay data. Semin Cell Dev Biol 2004, I5(6):703-7|3.

30. Yao B, Rakhade SN, Li Q, Ahmed S, Krauss R, Draghici S, Loeb JA: Accuracy of cDNA microarray methods to detect small gene expression changes induced by neuregulin on breast epithelial cells. BMC bioinformatics 2004, 5:99.

3I. Baker M, Wolanin P, Stock J: Systems biology of bacterial chemotaxis. Current Opinion in Microbiology 2006, 9:187-192.

32. Rajagopala S, Titz B, Goll J, Parrish J, Wohlbold K, MacKevitt M, Palzkill T, Mori H, Finley R, Uetz P: The protein network of bacterial motility. Mol Systems Biol 2007, 3:128.

33. Barak R, Eisenbach M: Correlation between phosphorylation of the chemotaxis protein CheY and its activity at the flagellar motor. Biochemistry 1992, 31(6): |82|-|826.

34. Khan IH, Reese TS, Khan S: The cytoplasmic component of the bacterial flagellar motor. PNAS 1992, 89(13):5956-5960.

35. Szurmant $\mathrm{H}$ and Ordal, $\mathrm{G}$.: Diversity in chemotaxismechanisms among the bacteria and archeae. Microbiology and Molecular Biology Reviews 2004, 68(2):301-319.

36. Wang L, Makino S, Subedee A, Bogdanove AJ: Mutational analysis reveals novel candidate virulence factors in the rice pathogen Xanthomonas oryzae pv. oryzicola. Appl Environ Microbiol 2008, 73:8023-8027.

37. Yao J, Allen C: Chemotaxis Is Required for Virulence and Competitive Fitness of the Bacterial Wilt Pathogen Ralstonia solanacearum. J Bacteriol 2006, I 88(10):3697-3708.

38. Beier $D$ and Gross, R.: Regulation of bacterial virulence by twocomponent systems. Current Opinion in Microbiology 2006, 9:143-152

39. West $A H$, Stock AM: Histidine kinases and response regulator proteins in two-component signaling systems. Trends Biochem Sci 200I, 26:369-376.

40. Lejona S Aguirre, A., Cabeza, M., Ve'scovi, E., and Soncini, F.: Molecular characterization of the Mg2+ responsive PhoP-PhoQ regulon in Salmonella enterica. J Bacteriol 2003, 185(2I):62876294.

4I. Zwir I, Shin D, Kato A, Nishino K, Latifi T, Solomon F, Hare J, Huang $\mathrm{H}$, Groisman E: Dissecting the PhoP regulatory network of Escherichia coli and Salmonella enterica. Proc Natl Acad Sci 2005. 102(8):2862- 2867

42. Lee SW, Han SW, Park KS, Ronald PC: The PhoP/Q two-component system is required for AvrXA2I activity, activation of hrp gene expression, and virulence in Xanthomonas oryzae pv. oryzae. J Bacteriology in press 2007.
43. Ryan R, Fouhy Y, Lucey J, Crossman L, Spiro S, He YW, Zhang LH, Heeb S, Cámara M, Williams P, Dow M: Cell-cell signaling in Xanthomonas campestris involves an HD-GYP domain protein that functions in cyclic di-GMP turnover. PNAS 2006, I3(I7):

44. Xiao YL, Li YR, Liu ZY, Xiang Y, Chen GY: Establishment of the hrp-inducing systems for the expression of the hrp genes of Xanthomonas oryzae pv. oryzicola. Wei Sheng Wu Xue Bao 2007. 47:396-40I

45. Wengelnik K, Ackerveken G, Bonas U: HrpG, a key hrp regulatory protein of Xanthomonas campestris pv. vesicatoria is homologous to two-component response regulators. Mol Plant-Microbe Interact 1996, 9:704-712.

46. Wengelnik K, Bonas U: HrpXv, an AraC-type regulator, activates expression of five of the six loci in the hrp cluster of Xanthomonas campestris pv. vesicatoria. J Bacteriol 1996, I 78:3462-3469.

47. Weber E, Koebnik R: Domain structure of HrpE, the Hrp pilus subunit of Xanthomonas campestris pv. vesicatoria. Journal of bacteriology 2005, 187(17):6175-6186

48. Furutani A. TS Oku T, Tsuno K, Inoue Y, Ochiai H, Kaku H, Kubo Y: Hpal secretion via type III secretion system in Xanthomonas oryzae pv. oryzae. J Gen Plant Path 2003, 69:27I-275.

49. Charkowski AO, Alfano JR, Preston G, Yuan J. He SY, Collmer A The Pseudomonas syringae pv. tomato HrpW protein has domains similar to harpins and pectate lyases and can elicit the plant hypersensitive response and bind to pectate. J Bacteriol 1998, 180:521।-5217.

50. Noël L, Thieme F, Nennstiel D, Bonas U: cDNA-AFLP analysis unravels a genomic-wide hrpG-regulon in the plant pathogen Xanthomonas campestris pv. vesicatoria. Molecular microbiology 200I, 4 I (6): | $27|-| 28 \mid$.

5I. Heithoff D Conner, C, Hanna, P, Julio, S, Hentschel, U, and Mahan, M: Bacterial infection as assessed by in vivo gene expression. PNAS 1997, 94:934-939.

52. Rainey $P$ and Preston, G.: In vivo expression technology strategies: valuable tools for biotechnology. Current Opinion in Biotechnology 2000, I I:440-444.

53. Tamir-Ariel D Navon, N., and Burdman, S.: Identification of genes in Xanthomonas campestris pv. vesicatoria induced during its interaction with tomato. J Bacteriol 2007, I89(17):6359-637I.

54. Le Brigand K Russell, R., Moreilhon, C., Rouillard, J. M., Jost, B., Amiot, F., V., Bole-Feysot, C., Rostagno, P., Virolle, V., Defamie, V., Dessen, P., Williams, G., Lyons, P., Rios, G., Mari, B., Gulari, E., Kastner, P. Gidrol, X., Freeman, T. C., Barbry, P.: An open-access long oligonucleotide microarray resource for analysis of the human and mouse transcriptomes. Nucleic Acids Res 2006, 34:e87.

55. Chou HH, Hsia AP, Mooney DL, Schnable PS: Picky: oligo microarray design for large genomes. Bioinformatics (Oxford, England) 2004, 20( I 7):2893-2902.

56. Integrated DNA Technology [http://www.idtdna.com]

57. ArrayCore Microarray Facility at the University of California, Davis [http://array.ucdavis.edu/home/contact.php]

58. Raghavachari N Bao, Y.P., Li, G., Xie, X., and Muller, U.R.: Reduction of autofluorescence on DNA microarrays and slide surfaces by treatment with sodium borohydride. Anal Biochem 2003, 31 2: 101-105.

59. Primer3 [http://frodo.wi.mit.edu]

Publish with Bio Med Central and every scientist can read your work free of charge

"BioMed Central will be the most significant development for disseminating the results of biomedical research in our lifetime. "

Sir Paul Nurse, Cancer Research UK

Your research papers will be:

- available free of charge to the entire biomedical community

- peer reviewed and published immediately upon acceptance

- cited in PubMed and archived on PubMed Central

- yours - you keep the copyright 